\title{
THE EFFECT OF PICTURE-WORD INDUCTIVE MODEL STRATEGY ON STUDENTS' WRITING SKILL IN DESCRIPTIVE TEXT
}

\author{
Beniario $^{1}$, Joni Saputra ${ }^{2}$ \\ Pendidikan Bahasa Inggris, Universitas Muhammadiyah Sumatera Barat \\ ²e-mail: jonisaputravivo123@gmail.com
}

\begin{abstract}
Abstrak
Tujuan dari penelitian ini adalah untuk mengetahui apakah siswa yang mendapat pengajaran dengan menggunakan Strategi Picture-Word Inductive Model memiliki perbedaan kemampuan dalam menulis teks deskriptif di kelas dua SMPN 2 Gunuang Omeh dibandingkan dengan siswa yang tidak mendapat pengajaran dengan menggunakan Strategi Picture-Word Inductive Model. Penelitian ini adalah penelitian kuasi eksperimen. Sample dari penelitian ini adalah siswa kelas dua SMPN 2 Gunuang Omeh yang berjumlah 54 siswa; kelas eksperimen adalah VIII.A terdiri dari 27 siswa dan kelas kontrol adalah VIII.B berjumlah 27 siswa. Instrumen yang digunakan dalam penelitian ini adalah tes rumpang. Setelah dilakukannya penelitian ini dengan mengaplikasikan Strategi Picture-Word Inductive Model hasil dari penelitian ini adalah nilai posttest kelas eksperimen meningkat dari nilai pretest. Ini bisa dilihat dari rata-rata nilai posttest pada kelas eksperimen adalah 77,59 yang meningkat dari nilai pretest 52,78. Nilai rata-rata posttest pada kelas control adalah 65,74 yang lebih rendah dari kelas eksperimen. Kesimpulan dari penelitian ini adalah siswa dengan penerapan pengajaran menggunakan Strategi Picture-Word Inductive Models lebih baik dibandingkan siswa yang tidak menerapkan pengajaran menggunakan Strategi Picture-Word Inductive Model dalam menulis teks deskriptif.
\end{abstract}

Kata Kunci: Strategi Picture-Word Inductive Model; writing; Teks Deskriptif

\begin{abstract}
The purpose of this research was to investigate the use of Picture-Word Inductive Model Strategy in teaching descriptive text at the eighth grade of SMPN 2 Gunuang Omeh. This research was Quasi Experimental research. The population of this research was the eighth grade of SMPN 2 Gunuang Omeh. The number of sample was 54 students; Experimental class was VIII.A consisting of 27 students, and Control class was VIII.B consisting of 27 students. The instrument used in this research was filling in the blank test. After conducting this research by using Picture-Word Inductive Model Strategy, the result of the posttest score of experimental class was getting higher than pretest score. It can be seen from the average posttest score of experimental class was 77.59 , increased from pretest score 52.78. The average posttest on control class was 65.74 was lower than Experimental class. As the conclusion, the students who received in class instruction of Picture-Word Inductive Model Strategy better than students who did not receive instruction of Picture-Word Inductive Model Strategy in writing descriptive text.
\end{abstract}

Keywords: Picture-Word Inductive Model Strategy; writing; Descriptive Text 


\section{INTRODUCTION}

Writing is one of the important skills should be master by students. Writing skill can be considered as process and products. The processes included choosing, drafting, revising, until publishing and product dealy with writing product. Writing becomes an important skill which should be achieved by the students because this skill is demanded in every learning activity in the classroom. In Junior High School, writing is included in every activities of teaching learning process, for example in doing tasks and examinations. Then, the Junior High School students usually should create such kind of tasks that demand their writing skill, so that the students should learn writing coherent and cohesion.

Based on curriculum of 2013, standard of writing competency in Junior High School at grade VIII is text writing. The genres of text is known as descriptive texts. The teaching process is expected to assist students in good writing skill whatever kinds of text tell about. Based on syllabus of Junior High School in odd semester, the students are expected to be able to write a descriptive text. They are able to make the generic structure of the text; identification and description. In term of identification, the students should identify the phenomenon to be described contains about the introduction of a person, place, animal or object was described. While in term of description, the students should reveal information about specific part of description such as animal, things, place or person. Revealing information is carried out by describing its features, forms, colors, or anything related to what the students describe.

In line with interview undertaken by researcher to English subject teacher on 12 April 2021, it showed that students in SMP 2 Gunuang Omeh had some problems in writing. First, the students had lack of vocabulary, so that students get difficulty in generating their idea such as determining the identifications and descriptions into sentences. Second, the students were not able to write a good paragraph because they did not have ideas or less idea with their writing descriptive text. So, it was difficult for them to start, arrange and organize their descriptive paragraphs, so that they do not write their paragraph well and they do not put their idea into paper. Third, the students do not know how to arrange the word into sentences, for instance adverb, noun, and adjective. The last is, they do not know how to start for the writing any text especially descriptive text.

Relating to the problems above, one of the ways to make the teaching writing effective is to make the students active and enjoy their learning and they can improve their' writing motivation and writing can be fun activity when the teachers apply appropriate strategy in teaching writing. The teacher should make students to be a good in writing. Students need learning strategy in order to help them become more active in learning process. Basically in learning concern the way teachers organize and use strategy of learning. One of the strategies in teaching writing descriptive is Picture-Word Inductive Model. Picture-Word Inductive Model is strategy that can be applied to various level of students. It also can be focused on all language skill, especially in writing. This strategy can help students writing a descriptive text by googling objects and actions in the picture, identifying the picture, saying the words, and adding the word into sentences then 
paragraph. So, this strategy gave students opportunities to think about what have learned and how it can be used in the real word in writing activities and also to check understanding of the lesson in the classroom. Besides, the strategy gives solution for students work with patners, ask and help each other, and make the students active and enjoy to learn writing process. In applying this strategy, students made a group: the author and the reader.

Based on the statement, the purpose used of Picture-Word Inductive Model Strategy as an alternative strategy for teaching English, especially for teaching writing ability in descriptive text. Finally, the researcher was interested to conduct a research to find out whether the students who are taught by using Picture-Word Inductive Model Strategy have different ability in writing descriptive text than the students who are not taught by using Picture-Word Inductive Model Strategy at the grade eight of SMPN 2 Gunuang Omeh.

\section{RESEARCH METHOD}

The design of this research was a quasi-experimental research type pretest and posttest control group design. A quasi-experiment is an empirical interventional study used to estimate the causal impact of an intervention on target population without random assignment. Quasi-experimental research shares similarities with the traditional experimental design or randomized controlled trial, but it specifically lacks the element of random assignment to treatment or control. Instead, quasi-experimental designs typically allow the researcher to control the assignment to the treatment condition, but using some criterion other than random assignment. The most commonly used of Quasi experimental designs in educational research could be represented as:

$\begin{array}{llll}\text { Experimental } & O_{1} & X & O_{2} \\ \text { Control } & O_{3} & & O_{4}\end{array}$

(Creswell, 2005:255).

This design requires at least two groups, each of which is formed by assignment but not random assignment. Both groups administrated a pretest and each group receives different treatment. Both groups would be tested at the end of the study. Posttest score would be compared to determine the effect of the treatment. This research consisted of two variables; the independent variable symbolized by " $\mathrm{X}$ " that is the use of Picture-Word Inductive Model (PWIM) Strategy and the dependent one as "Y" which referred to students' writing skill. In brief, the research designed by following table.

Table 1. Quasi Experimental Research

\begin{tabular}{|c|c|c|c|}
\hline Class & Pretest & Treatment & Posttest \\
\hline Control & $X_{1}$ & $Z$ & $X_{2}$ \\
\hline Experimental & $Y_{1}$ & $T$ & $Y_{2}$ \\
\hline
\end{tabular}

where:

Z : treatment Control Group (Conventional Strategy)

$T \quad$ : treatment Experimental Group (Picture-Word Inductive Model Strategy) 
$X_{1}$ and $Y_{1} \quad$ : the pretest for both two group

$X_{2}$ and $Y_{2} \quad$ : the posttest for both two group

According to Creswell, $(2005: 255)$, instrument is the tool use to collect the data from the respondent of the research. The instrument of this research was written test. The test was filling the blank. The students were asked to fill the blank line related topics on syllabus. In the instrument of pretest and posttest, the students were asked to fill the blank line about descriptive text by choosing one of topics provided.

Before conducting the pretest, to know the result of the students' ability on descriptive text the researcher gave a test that relate the elective topics related topics on syllabus to assess the students' ability on descriptive text. The researcher determined the test based on the curriculum and teaching materials. The test is held twice; pretest and posttest. Before giving the test to the students, the researcher tested the instruments. It was done in two classes; control and treatment.

To analyze the implementation of using Picture Word Inductive Model (PWIM) Strategy, the researcher used some formulas in this experimental research. The result data was calculated by using N-Gain $(G)$ between pretest and posttest. The formula as follow:

$$
G=\frac{S_{\text {post }}-S_{\text {pre }}}{S_{\text {maks }}-S_{\text {pre }}},
$$

where:

G : N-Gain score,

$S_{\text {post }}$ : posttest score,

$S_{\text {pre }}:$ pretest score,

$S_{\text {maks }}:$ maximum ideal score.

Table 2. The Criteria of Achievment N-Gain Score

\begin{tabular}{|c|c|}
\hline Limitation & Category \\
\hline$G \geq 0,7$ & High \\
\hline $0,3<G<0,7$ & Middle \\
\hline$G \leq 0,3$ & Low \\
\hline
\end{tabular}

(Meltzer, 2002).

To analyze the data, the researcher compared mean score by using t-Test when the data is normal and homogeneous or uses Mann-Whitney U Test if data is not normal or not homogeneous.

\section{t-Test}

$$
t=\frac{\overline{x_{1}}-\overline{x_{2}}}{\sqrt{\frac{s_{1}{ }^{2}}{n_{1}}+\frac{s_{2}^{2}}{n_{2}}}},
$$


where:

$t \quad:$ t-test,

$\overline{x_{1}} \quad$ : mean score of experiment class,

$\overline{x_{2}} \quad$ : mean score of control class,

$s_{1}{ }^{2}$ : standard deviation of experiment class,

$S_{2}{ }^{2}$ : standard deviation of control class,

$n_{1} \quad$ : number of students of the experiment class,

$n_{2} \quad$ : number of students of the control class,

(Zulkarnain, 2010:187).

Hypothesis:

- $\quad H_{0}$ : not significant difference between giving treatment and without treatment

- $H_{1}$ : differ significant between giving treatment and without treatment

Criterion for acceptance:

- $\quad$ If sig $>\alpha$, accept $H_{0}$

- $\quad$ If sig $<\alpha$, reject $H_{1}$

\section{Normality Test}

Normality test is used to know the distribution data normal or not. To find out the distribution data is used normality test with chi-square. The researcher used Chi-square formula, as follows:

$$
\chi^{2}=\sum_{i=1}^{k} \frac{\left(O_{i}-E_{i}\right)^{2}}{E_{i}}
$$

where:

$\chi^{2} \quad:$ chi-square,

$O_{i} \quad$ : frequency that was obtained from data,

$E_{i} \quad$ : frequency that was hoped,

$k \quad:$ the sum of interval class.

Hypothesis:

- $H_{0}$ : population is normally distributed

- $H_{1}$ : population is not normally distributed

Criterion for acceptance:

- If $\chi^{2}<\chi^{2}$ table, accept $H_{0}$

- If $\chi^{2}>\chi^{2}$ table, reject $H_{1}$ 


\section{Homogenity Test}

Homogeneity test is used to compare variance in a group of three categories data or more and its categories can be compared fairly if the categories are homogeneity.

$$
\begin{gathered}
S_{X}{ }^{2}=\sqrt{\frac{\sum X^{2}-\left(\sum X\right)^{2}}{n(n-1)}}, \\
S_{Y}{ }^{2}=\sqrt{\frac{\sum X^{2}-\left(\sum X\right)^{2}}{n(n-1)}}, \\
F=\frac{S_{b}}{S_{s}},
\end{gathered}
$$

where:

$S_{X}$ and $S_{Y} \quad$ : standard deviation of $X$ and Y, respectively,

$F \quad$ : rasio of both standard deviation,

$\sum X$ and $\sum X^{2}$ : mean of $X$ and $X^{2}$, respectively,

$n \quad$ : amount of sample,

$S_{b} \quad$ : biggest standard deviation,

$S_{s} \quad$ : smallest standard deviation.

Hypothesis:

- $H_{0}: \sigma_{1}{ }^{2}=\sigma_{2}{ }^{2}$ (variance homogeneous)

- $H_{1}: \sigma_{1}^{2} \neq \sigma_{2}^{2}$ (variance nonhomogeneous)

Criterion for acceptance:

- If $F<F$ table, accept $H_{0}$

- If $F>F$ table, reject $H_{1}$

\section{Mann Whitney U Test}

If the data is not normally distributed and nonhomogeneous, the researcher used Mann Whitney U test as the form to calculate the data:

$$
\begin{aligned}
& U_{1}=n_{1} \cdot n_{2}+\frac{n_{1}\left(n_{1}+1\right)}{2}-R_{1}, \\
& U_{2}=n_{1} \cdot n_{2}+\frac{n_{2}\left(n_{2}+1\right)}{2}-R_{2},
\end{aligned}
$$

where:

$U_{1} \quad$ : amount of level 1 ,

$U_{2}$ : amount of level 2,

$n_{1}$ : amount of sample 1 ,

$n_{2} \quad$ : amount of sample 2,

$R_{1} \quad$ : amount of rank sample 1 , 
$R_{2} \quad$ : amount of rank sample 2 ,

(Sugiono, 2011:153).

\section{RESULTS AND DISCUSSION}

This research was carried out at eight grade of SMPN 2 Gunuang Omeh. The population was all of the students at grade VIII of SMP 2 Gunuang Omeh.

Table 3. Population of the Research

\begin{tabular}{|c|c|c|}
\hline No. & Classes & Total of Student \\
\hline 1 & VIII/1 & 27 students \\
\hline 2 & $\mathrm{VIII} / 2$ & 27 students \\
\hline 3 & VIII/3 & 27 students \\
\hline \multicolumn{2}{|c|}{ Total } & 81 students \\
\hline
\end{tabular}

A sample is part of the population being examined at the time of research. Thus, the sample of research should be less than the population. The sample must have the characteristics, which represent all the population being observed in the research. It enables the researcher to collect and organize the data more effectively and practically. In this research, researcher determined the classes based on students score to see students have equal ability. After calculating the score, researcher gets the result that students' average score of classes. Then, the researcher is going to find the normality and homogeneity of the classes. If the researcher already got the normality and homogeneity of the classes then the researcher determined two classes as the sample of this research by using lottery, before doing that, researcher commits the first taken out is experiment class and the second is control class.

The researcher took two classes; VIII/1 and VIII/2 as the sample because the number of these classes was homogeneous. The determination of assigning the classes to be control and experimental classes also based on the English teacher's analysis who taught the classes at SMP 2 Gunuang Omeh that the students' writing skill was categorized in the same level.

\section{Table 4. Sample of the Research}

\begin{tabular}{|c|c|c|}
\hline No. & Classes & Total of Student \\
\hline 1 & VIII/1 & 27 students \\
\hline 2 & VIII/2 & 27 students \\
\hline \multicolumn{2}{|c|}{ Total } & 54 students \\
\hline
\end{tabular}

The control class is VIII.A and VIII.B as the experimental class. The decision in determination whether control or experimental class was decided 
randomly. In experimental class, the students were taught by using the PictureWord Inductive Model Strategy. While, in control class the students were taught by using conventional strategy.

Prior to pretest was executed the research should determine three variables which play significant role in identifying the nature of the classes. The variable are normality test, homogeneity test and data t-test. Both of classes possess the equal average quality during pr-test, but they possess different strategy in teaching descriptive text writing.

The study used the help of SPSS software for data processing. Here are the results of data processing with normality test, homogeneity test, and t-test for the pretest and posttest.

\section{Pretest}

Table 5. Descriptive Statistic of Pretest Score

\begin{tabular}{|c|c|c|c|c|c|}
\hline \multirow[b]{2}{*}{ Class } & \multirow[b]{2}{*}{$\mathrm{N}$} & \multicolumn{3}{|c|}{ Test of Mastery Concept } & \multirow[b]{2}{*}{$\begin{array}{l}\text { Ave } \\
\text { rage }\end{array}$} \\
\hline & & $\begin{array}{l}\text { Ideal } \\
\text { Score }\end{array}$ & $\begin{array}{l}\text { Min. } \\
\text { Score }\end{array}$ & $\begin{array}{l}\text { Max } \\
\text { Score }\end{array}$ & \\
\hline $\begin{array}{l}\text { Experi } \\
\text { mental }\end{array}$ & 27 & 100 & 0 & 100 & 52.77 \\
\hline Control & 27 & 100 & 0 & 100 & 48.88 \\
\hline
\end{tabular}

On Table 5 above, it showed that minimum score on the test of experimental class was 00.00 and control class was 00.00 also. While in maximum score on experimental class and control class having equal score t the average of written test on pretest from the average showed experimental class was 55.77 and control class was 48.88 It can be concluded that experimental class had knowledge was higher than control class that was having 55.77 as the average score.

Table 6. Normality Test of Pretest

\begin{tabular}{|c|c|c|c|c|}
\hline Class & $\begin{array}{c}\text { Asy. } \\
\text { Sig. } \\
(2- \\
\text { tailed) }\end{array}$ & $\alpha$ & $\begin{array}{c}\text { Hypo } \\
\text { thesis }\end{array}$ & $\begin{array}{c}\text { Distri } \\
\text { bution }\end{array}$ \\
\hline $\begin{array}{c}\text { Experi } \\
\text { mental }\end{array}$ & 0.331 & 0.05 & $\begin{array}{c}\text { Accept } \\
H_{0}\end{array}$ & Normal \\
\hline Control & 0.229 & 0.05 & $\begin{array}{c}\text { Accept } \\
H_{0}\end{array}$ & Normal \\
\hline
\end{tabular}

From the Table 6 above, it showed normality test that done of pretest on experiment class and control class that the distribution of data was normal. Experiment class in Asymp. Sig. (2-tailed) was 0.331 with significant level was 0.05 , if the data value of Asymp. Sig. (2-tailed) $0.331>0.05$, it meant that the 
distribution of data was normal and the Control class value of Asymp. Sig. (2tailed) $0.229>0.05$, it meant that the data distribution also was normal.

Table 7. Homogenity Test of Pretest

\begin{tabular}{|c|c|c|c|}
\hline $\begin{array}{c}\text { Trimmed } \\
\text { Mean }\end{array}$ & $\alpha$ & $\begin{array}{c}\text { Hypo } \\
\text { thesis }\end{array}$ & Distribution \\
\hline 0.315 & 0.05 & $\begin{array}{c}\text { Accept } \\
H_{0}\end{array}$ & Homogeneous \\
\hline
\end{tabular}

With regard to Table 7, homogeneity test of pretest gained value of based on trimmed mean that was 0.315 with significant level 0.05 , that was why said that the pretest on experiment class was coming from homogeneous variance when based on trimmed mean $0.315>0.05$, it meant that pretest data both the classes were from the homogeneous variance.

Table 8. t-Test Result of Pretest

\begin{tabular}{|c|c|c|c|}
\hline $\begin{array}{c}\text { Asy. Sig. } \\
\text { (2-tailed) }\end{array}$ & $\alpha$ & Hypothesis & Significance \\
\hline 0.279 & 0.05 & Accept $H_{0}$ & $\begin{array}{c}\text { Not differ } \\
\text { significant }\end{array}$ \\
\hline
\end{tabular}

As the Table 8 above, t-test of both classes; experimental and control were not differ significant. It occurred since the value of Asymp. Sig.(2-tailed) was 0.269. It meant that Asymp. Sig.(2-tailed) $0.279>$ significant level 0.05. Here, the researcher concluded that the students' ability in writing descriptive text of experimental class and control class were equal and not differ significant.

\section{Posttest}

Table 9. Descriptive Statistic of Posttest Score

\begin{tabular}{|c|c|c|c|c|c|}
\hline \multirow[b]{2}{*}{ Class } & \multirow[b]{2}{*}{$\mathrm{N}$} & \multicolumn{3}{|c|}{ Test of Mastery Concept } & \multirow[b]{2}{*}{$\begin{array}{l}\text { Ave } \\
\text { rage }\end{array}$} \\
\hline & & $\begin{array}{l}\text { Ideal } \\
\text { Score }\end{array}$ & $\begin{array}{l}\text { Min. } \\
\text { Score }\end{array}$ & $\begin{array}{l}\text { Max } \\
\text { Score }\end{array}$ & \\
\hline $\begin{array}{l}\text { Experi } \\
\text { mental }\end{array}$ & 27 & 100 & 15.00 & 100 & 77.59 \\
\hline Control & 27 & 100 & 20.0 & 100 & 65.74 \\
\hline
\end{tabular}

Referring to the Table 9 showed, the minimum score and the average score of posttest on experiment class was getting higher than control class. The minimum score for experiment class was 15.00, while the control class was 20.00. The maximum score on the control class was 100, and the score gained by experiment class 100. Moreover, the average of posttest class on experiment class was 77.59 and the control class for the average of posttest was 65.74. The conclusion of the table above can be seen that for the posttest score the experiment class was higher than control class after giving some treatments. 
Table 10. Normality Test of Posttest

\begin{tabular}{|c|c|c|c|c|}
\hline Class & $\begin{array}{c}\text { Asy. } \\
\text { Sig. } \\
(2- \\
\text { tailed })\end{array}$ & $\alpha$ & $\begin{array}{c}\text { Hypo } \\
\text { thesis }\end{array}$ & $\begin{array}{c}\text { Distri } \\
\text { bution }\end{array}$ \\
\hline $\begin{array}{c}\text { Experi } \\
\text { mental }\end{array}$ & 0.424 & 0.05 & $\begin{array}{c}\text { Accept } \\
H_{0}\end{array}$ & Normal \\
\hline Control & 0.392 & 0.05 & $\begin{array}{c}\text { Accept } \\
H_{0}\end{array}$ & Normal \\
\hline
\end{tabular}

On the Table 10, the normality test of posttest on experiment class and control class had normal distribution. Here experiment class had the column Asymp. Sig.(2-tailed) 0.424, it compared with significant level 0.05. Asymp. Sig.(2-tailed) $0.424>0.05$, it meant that data was normal. While the control class got Asymp. Sig.(2-tailed) 0.392 with significant level 0.05. It was also normal since Asymp. Sig.(2-tailed) $0.392>0.05$.

Table 11. Homogenity Test of Posttest

\begin{tabular}{|c|c|c|c|}
\hline $\begin{array}{c}\text { Trimmed } \\
\text { Mean }\end{array}$ & $\alpha$ & $\begin{array}{c}\text { Hypo } \\
\text { thesis }\end{array}$ & Distribution \\
\hline 0.155 & 0.05 & $\begin{array}{c}\text { Accept } \\
H_{0}\end{array}$ & Homogeneous \\
\hline
\end{tabular}

Pertaining to Table 11 above, the value of trimmed mean was 0.155 with level significant 0.05 . Based on trimmed mean was higher than level significant 0.05. It could be said posttest data on experimental and control class were homogeneous variance because trimmed mean $0.155>0.05$. It meant that homogeneous.

Table 12. t-Test Result of Posttest

\begin{tabular}{|c|c|c|c|}
\hline $\begin{array}{c}\text { Asy. Sig. } \\
\text { (2-tailed) }\end{array}$ & $\alpha$ & Hypothesis & Significance \\
\hline 0.00 & 0.05 & Reject $H_{0}$ & $\begin{array}{c}\text { Differ } \\
\text { significant }\end{array}$ \\
\hline
\end{tabular}

Based on Table 12 provided above, it showed that t-test of posttest on control and experimental class were differ significant, because Asymp. Sig.(2tailed) $0.00<0.05$. It could be concluded that both of classes were differ significant. It meant that the Picture-Word Inductive Model Strategy gave effect to the students in writing a descriptive text by teamwork and become creative to discuss the material. 


\section{CONCLUSION}

Based on the results above, it can be concluded that the students were taught by using Picture-Word Inductive Model Strategy better than the students were not taught by using Picture-Word Inductive Model Strategy in writing descriptive paragraph at the eighth grade of SMPN 2 Gunuang Omeh. It can be seen from the average posttest score of experimental class was 77.59, increased from pretest score 52.78. The average posttest on control class was 65.74 , lower than Experimental class. Hence, the implementation of PWIM can be categorized as good strategy and gave significance effect on students' posttest. The students taught by using Picture-Word Inductive Model Strategy in writing descriptive had difference ability.

\section{ACKNOWLEDGEMENTS}

The writer would like to express his gratitude to Allah Subhanahu wa Ta'ala for all graces, facilities, easiness, helps, and guidances to start and finish this study. Then the writer would like to express his gratitude to Messenger of Allah Muhammad Shalallahu 'Alaihi wa Sallam for all struggles, loves, pray and clear guidance that he left. And to beloved parents who facilitate writer with many stuff to finish this study and to his brother and sister for their supports. The writer also would like to express his gratitude to any parties in SMPN 2 Gunuang Omeh and FKIP University of Muhammadiyah Sumatera Barat who had helped writer to conduct and finish this study.

\section{REFERENCES}

Blanchard, K. \& Root, C. (2012). Ready to Write. Longman: Pearson Education.

Calhoun, E.F. (1999). Teaching Beginning Reading and Writing with the Picture Word Inductive Model. Alexandria, VA: Association for Supervision and Curriculum Development.

Creswell, J.W. (2005). Educational Research Planning, Conducting, and Evaluating Quantitative and Qualitative Research. Second Edition. USA: University of Nebraska-Linclon.

Ewen, D. (2005). Writing and Learning Centre: Workbook on Writing Paragraph. Ontario College of Art and Design.

Hammond, J. (1992). English for Special Purposes. National Centre for English Language Teaching ad Research. Sydney: Macquarie University.

Jacobs, H. (1998). Testing ESL Composition: Practical Approach. Rowley: Newbury House Publishers, Inc.

- (1981). Testing ESL Composition Profile, A Practical Approach. Rowley Ma: Newbury House Publisher Inc.

Kane, T. (2000). The Oxford: Essential Guide to Writing. New York : Oxford University Press. Inc.

Linse, C.T. (2005). Practical English Language Teaching : Young Learners. New York : The McGraw-Hill Companies. Inc.

Meltzer, D.E. (2002). The relationship between Mathematics Preparation and Conceptual Learning Gains in Physic: A possible: "hidden variable" in diagnostic pretest score. American Journal. 
Merthens, N.L. (2010). Writing Processes, Tools, and Technique. New York: Nova Science Publishers, Inc.

Richards, J.C. \& Renandya, W.A. (2002). Methodology In Language Teaching. Cambridge : Cambridge University Press.

Rijlaarsdam, G., Bergh, Huub van den, \& Couzijn, M. (2005). Effective learning And Teaching Writing. New york.

Sugyono. (2010). Statistika untuk Penelitian. Bandung. CV.Alfabeta.

Weigle, S.C. (2002). Assessing Writing. Cambridge: Cambridge University Press.

Wishon, G.E. (1980). Let's Write English. USA: Litton Educational Publishing. Inc.

Wright, A. (2002). Pictures for Language Learning. (3rdEd.). Oak Leigh: Cambridge University Press.

Yuliana. (2011). The use of picture word inductive model (pwim) In teaching vocabulary An Experimental Research at The Seventh Grade of Madrasah Tsanawiyah Sunan Kalijaga Bawang Batang in The Academic Year of 2010/2011. Unpublished Thesis: IAIN Walisongo.

Zulkarnain. (2010). Statiska Penelitian. Pekanbaru: Cendekia Insani Pekanbaru. 